\title{
Investigation on Energy Consumption of an Olympic Ice Rink and Sports Facility
}

\author{
Hamdi Sunnetci ${ }^{1 *}$, Deniz Yilmaz ${ }^{2}$ \\ ${ }^{1}$ Istanbul Metropolitan Municipality-Enerji A.S., Istanbul, Turkey \\ ${ }^{2}$ Istanbul Arel University, Mechanical Engineering Department, Istanbul, Turkey
}

Corresponding Author Email: denizyilmaz@arel.edu.tr

https://doi.org/10.18280/ti-ijes.650117

Received: 22 December 2020

Accepted: 15 February 2021

\author{
Keywords: \\ refrigeration systems, ice rink, energy \\ consumption analysis
}

\begin{abstract}
In these days, people spend $87 \%$ of their time indoors. Therefore, buildings are responsible for $36 \%$ of the total energy consumption and $40 \%$ of the $\mathrm{CO}_{2}$ emissions in the world. Besides, energy expenditures can be reduced, especially through improvements in public buildings used by many people. In this study, an annual energy consumption was conducted for an Olympic ice-skating rink and sports complex in Istanbul with a capacity of 900 spectators, was analyzed. Annual energy consumption of the building was $2915032 \mathrm{kWh}$ electrical energy and $157944 \mathrm{~m}^{3}$ natural gas. It was foreseen that $40000 \mathrm{kWh}$ energy savings can be achieved annually with the evaporative pre-cooling system.
\end{abstract}

\section{INTRODUCTION}

When the distribution of energy consumption by sectors is analyzed, it is seen that the industry takes the first place, secondly, the buildings come with a very close consumption rate to the industry. Buildings consume approximately $40 \%$ of the total primary energy usage in the US and EU, $27.3 \%$ in China and 30\% in Turkey [1]. The most important application areas of efforts to reduce energy consumption and carbon dioxide emissions in buildings are "Public buildings". Many studies are being carried out by the governments on energy saving in public buildings. Service buildings are normally $60 \%$ more energy intensive than the residential buildings. Since most of the public buildings are old buildings, the aim here is the retrofitting of these buildings [2-7]. However, there are some obstacles that need to be solved before the issue of retrofitting the existing buildings [7-10]. To overcome these obstacles, governments' investments in energy policies are very important. One of the aims of the French government is to plan the renovation of 500000 homes per year and to make them energy efficient, and to cut the heat losses, power consumptions and carbon emissions. The government also plans to set aside some 4.8 billion euros for renovating the public-sector buildings, including schools and hospitals, to make them energy efficient. At the time of this study, building sector accounts for 45 percent of energy consumption and 27 percent of greenhouse gas emissions, additionally some 7 million homes were not adequately insulated [2-3]. The UK government has successfully reduced greenhouse gas emissions by providing a variety of incentive mechanisms to improve energy according to the national energy policy. The projection is to reduce greenhouse gas emissions by $80 \%$ from 1990 to 2050 [13]. For China, the statistics show that the electrical energy consumption per square meter in large public buildings is 70 to $300 \mathrm{kWh}$, which is $10-20$ times higher than in residential buildings. Therefore, the government has introduced some mandatory regulations aimed at increasing the energy efficiency of the public buildings. These regulations aim to save $50 \%$ of the energy especially in new public buildings [14-15].

In Turkey, while $30 \%$ of the energy is consumed by the buildings, especially with the regulations related to the energy performance, it is known that up to $50 \%$ of the energy consumption would be saved. There are many studies carried out by the European Union about energy efficiency at the buildings. The Energy Performance of Buildings Directive (EPBD) plays an important role on this issue. According to this directive all the new buildings must be nearly zero-energy buildings (NZEB) starting from 31 December 2020. (Since 31 December 2018, all new public buildings already need to be NZEB). One of the regulations stipulated by the laws in force in Turkey is about the "Energy Performance of the Buildings". This regulation's aim is to develop methods to evaluate all kinds of energy usage in buildings; to classify them in terms of $\mathrm{CO}_{2}$ emissions and types of energy used, to assess minimum energy efficiency criteria, to implement these criteria to the existing buildings and to evaluate the usage opportunities of renewable energy sources for the new and existing buildings. The regulation also covers architectural, mechanical, and electrical design and applications. Thus, it provides adjustments about the issues such as heating, cooling, lighting; renewable energy sources; building layouts; energy efficiency certificates; regular inspections of heating and ventilation systems; training and certification of energy performance auditing personnel.

In this study, one of the biggest sports complexes in Istanbul, was selected for energy analysis. In the scope of this study, field measurements were carried out to analyze the amount of energy consumption at the ice rink and as a result of these measurements; alternative solutions that would improve energy efficiency were evaluated. 


\section{METHODOLGY}

\subsection{Olympic ice rink building}

For heating, the plant is fed from a single center and there are two $1000 \mathrm{~kW}$ double fuel heating boilers in the boiler room. Fan coil units, air conditioning units and hot water supply system are fed from there. The air conditioning system is operated through automation. As the fuel source, natural gas is used. For the hot water requirements, there are 4 accumulation and boiler tanks with $1000 \mathrm{~L}$ capacity. There is one $626 \mathrm{~kW}$ air-cooled chiller unit located on the rooftop of the facility to meet the cooling requirements and two ammonia gas chillers with $250 \mathrm{~kW}$ cooling capacity to provide cooling in the ice-skating rink. Air cooled groups, Fan Coil Units (FCU) and air conditioning units are supplied from these units. Three of the facility's six air handling units are operated with fresh air and three of them with mixed air. While the heating system operates for the whole building through fan coils and air conditioning units, the chillers as the cooling sources provide cooling with fresh air conditioning units and fan coils in the rooms. Fan coil devices in the offices and rooms on different floors provide cooling with cold water coming from the chillers during the cooling season. The fan coil units used were selected as 2-pipe type. All parts of the facility operate during the whole year, in summer and winter. Ice rink chillers and boilers are active in summer and winter, while the aircooled chiller operates only in summer. The general features of the building are listed in Table 1 and Figure 1 shows a general view of the ice rink area.

Table 1. Building specifications

\begin{tabular}{cc}
\hline Construction Year & $\mathbf{2 0 0 7}$ \\
\hline Purpose of usage & Olympic ice rink and sport \\
complex \\
Constructional area & $6145 \mathrm{~m}^{2}$ \\
Number of degree days for heating & 1662 \\
Number of degree days for cooling & 255 \\
Heating / Cooling System & Boiler / Chiller (with R717) \\
\hline
\end{tabular}

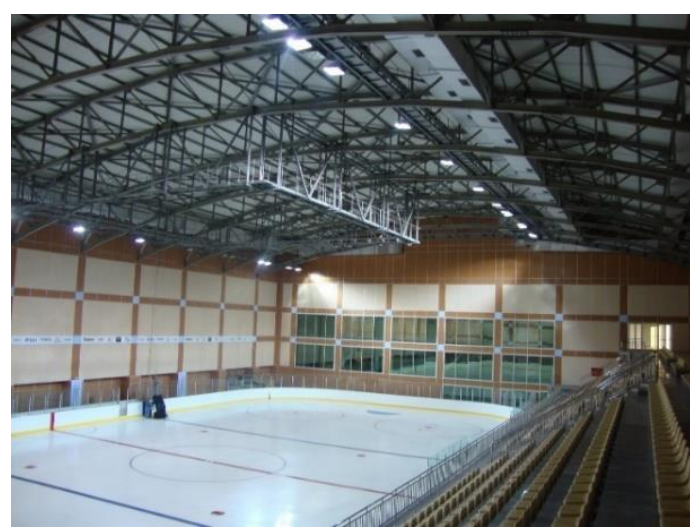

Figure 1. Overview of the facility

\subsection{Refrigeration system}

The cooling requirement of the facility is met by an aircooled chiller unit with a $626 \mathrm{~kW}$ cooling capacity. Refrigeration unit is used for FCU and air handling units. The facility also has 2 ammonia chillers and 2 cooling towers with a $250 \mathrm{~kW}$ cooling capacity for the ice skating rink. Cooling groups are monitored and managed by automation system.
With the air-cooled refrigeration unit, the facility is cooled in the summer period, and the ammonia chillers is used to cool the ice rink all year round. The engine room is shown in Figure 2 .

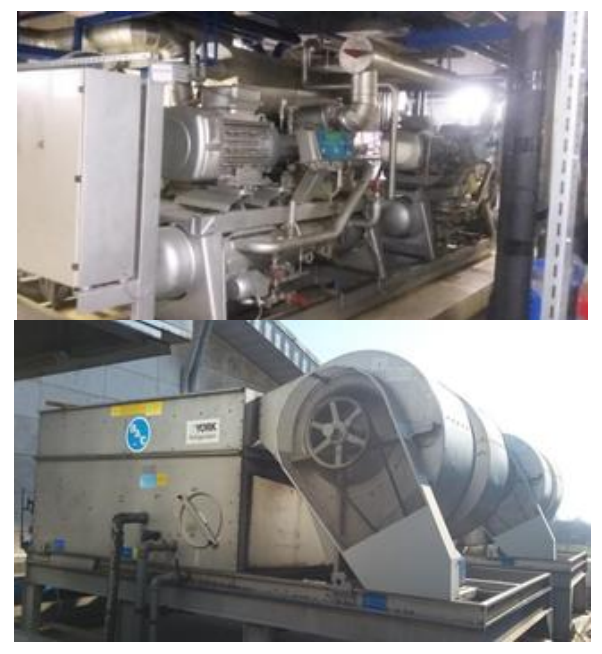

Figure 2. Machine room and cooling towers

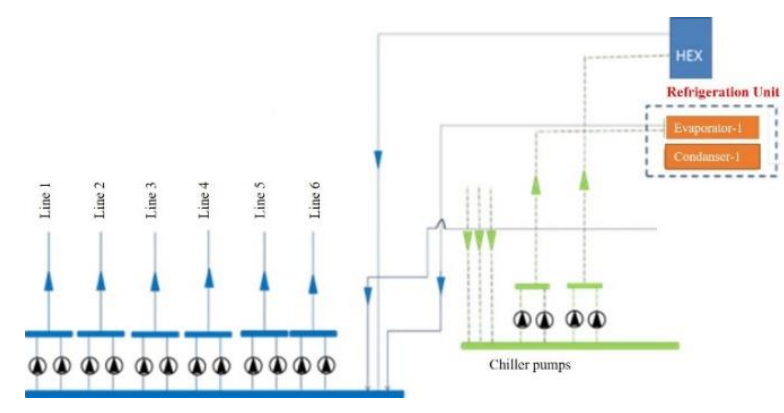

Figure 3. Refrigeration unit mechanical system diagram

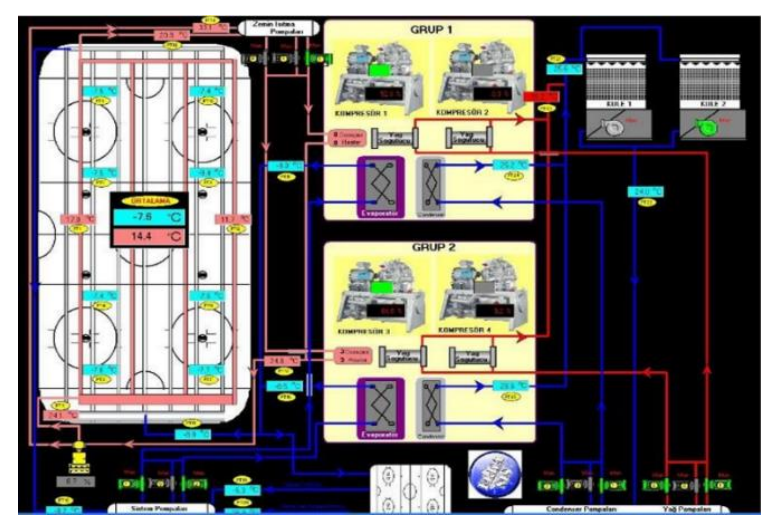

Figure 4. Ammonia chiller mechanical system scheme of the facility

Table 2. Characteristics of Chillers

\begin{tabular}{ccc}
\hline & \multicolumn{2}{c}{$\begin{array}{c}\text { Refrigeration Units } \\
\text { ChillerAmmonia Chillers }\end{array}$} \\
\hline Quantity & 1 & 2 \\
Cooling Power (kW) & 626 & 250 \\
Compressor Consumption (kW) & 195 & \\
& & 84 \\
Coefficient of Performance (COP) & 3.21 & 2.98 \\
Compressor Type & Screw & Screw \\
Number of Compressors & 2 & 2 \\
Refrigerant & R134a & R717 \\
\hline
\end{tabular}


The system diagram of the facility's air-cooled refrigeration unit is shown in Figure 3. Cold glycol water produced in the evaporator of the chiller and ammonia chiller unit. Than it is sent to the system through the heat exchanger and cools the building with 6 lines. The cooling project of the facility's ammonia chiller is shown on the automation image in Figure 4.

As seen in Figure 4, the fluid produced in chillers is sent to the ice rink line with 3 system pumps. 2 pumps are integrated into the cooling tower to cool the compressor oil circuit and condenser line. In addition, it supports the air cooled chiller group through the accumulation tank and heat exchanger connected to the collector of the air cooled group. Another feature of the system is the recovery of the heat released during the compression of ammonia for the hot use of the plant.

\subsection{Measurements}

Electrical measurements were taken in refrigeration units, pipings, motors, equipment's (fans, pumps, etc.) and compressors. For the flow measurements of the Air Handling Units and Rooftop units, the Handheld TUF-2000H portable ultrasonic flow meter was used. Testo 470 optical mechanical speed meter was used for speed measurements. Testo815 sound meter was used for sound level measurements. Testo 435-1 was used as the lux meter. Testo $U$ temperature probe was used for measurement of wall $U$ values and for air vents and air handling units, anemometer was used.

\section{RESULTS}

\subsection{Annual energy consumptions}

Figure 5 shows that the $66 \%$ of total energy consumption comes from electricity and the $34 \%$ from natural gas. Electricity has the largest share in energy consumption. It is observed that the share of natural gas, which has a share of $34 \%$ according to the distribution of consumption, has decreased to $16 \%$ in the cost distribution. The low cost of natural gas has a direct impact on the decrease in its share in the total cost. Natural gas is consumed for heating purposes in winter and for hot water production in summer.

As can be seen in Figure 6, the remarkable point is that the electricity consumption trend is generally higher in summer months. This is a result of the electricity consumption of the electric motors belonging to the refrigeration units and auxiliary equipment's (pumps, etc.) that operate for the airconditioned areas in the summer months. The upward trend, which started in May, continued in September. With the deactivation of the chiller which takes part in the cooling of the rooms, a downward trend is observed again.

In addition, since the facility has an ice-skating rink, there is an ammonia refrigeration system which is active in both summer and winter. Since this chiller and auxiliary equipment's are constantly in use, they cause high electricity consumption in winter as well.

As the facility is examined in terms of natural gas, consumption is given in Figure 7 . The greatest natural gas consumption is in winter when the need for heating occurs. When we examine the consumption in winter, natural gas consumption is high between January-April and NovemberDecember and reaches its highest level in January. All the heating boilers in the building were installed for the purpose of heating the building and producing hot water. Natural gas consumption in the summer months occurs to meet the hot water demand.

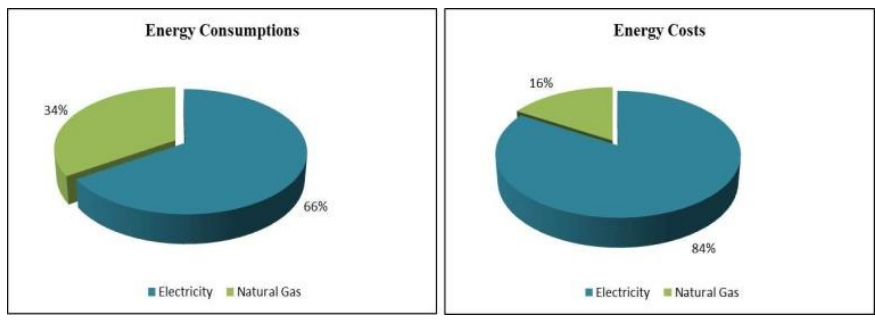

Figure 5. Percentages of energy consumptions and costs
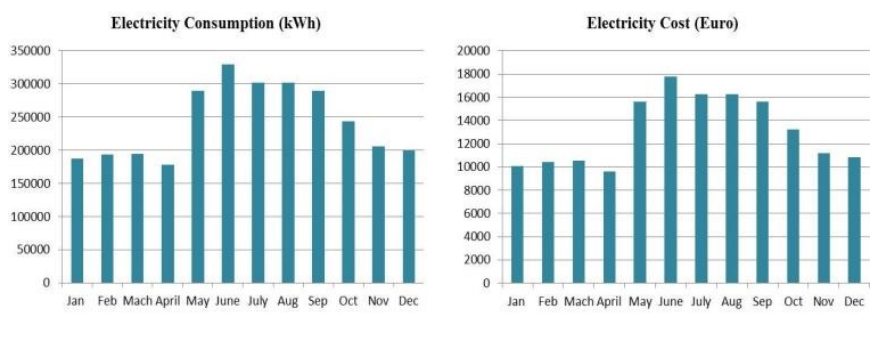

Figure 6. Amount of electricity consumption in (kWh) and (Euro)

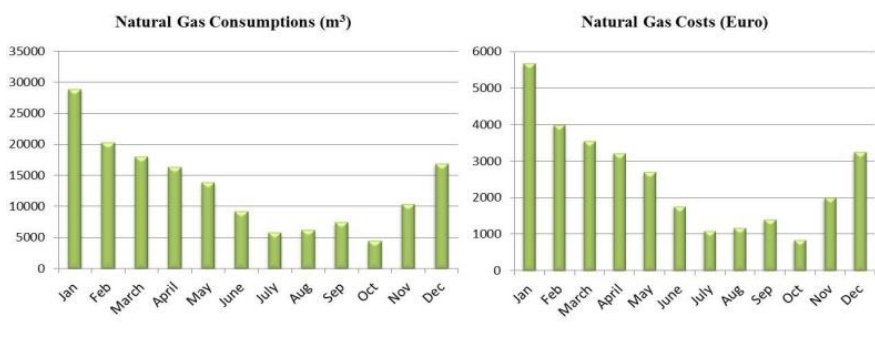

Figure 7. Amount of natural gas consumption in $\left(\mathrm{m}^{3}\right)$ and (Euros)

\subsection{Consumption analysis}

The number of degree days of heating (HDD) and cooling (CDD) in Istanbul and the energy consumption of the building are correlated with the degree days of energy consumption of the facility. The degree day statistics were used to correlate the plant's energy consumption during the year with the climatic conditions during the year in the region where the facility is located. Table 3 clearly shows how energy consumption changes according to the climate. Degree day is a unit for measuring how much of a 24-hour period is hot and how much is cold. Heating Degree Days (HDD) value describes the intensity of the cold weather that, the outdoor and room temperatures at a given time (day, month, year) are taken, while Cooling Degree Days (CDD) value describes the intensity of the hot weather that, the outdoor temperature at a given time (day, month, year) is taken. The threshold value for the HDD is $15^{\circ} \mathrm{C}$ and the HDD value is zero when the ambient temperature is above this value. The threshold value for CDD is $22^{\circ} \mathrm{C}$. The HDD and CDD values in Table 5 are the sum of the daily results monthly. In short, the HDD and CDD indicate the need for heating and cooling according to the season.

Knowledge of the sum of heating or cooling day temperatures is important to know the energy requirement for heating or cooling the buildings. If the outside temperature is 
above $15^{\circ} \mathrm{C}$, heating is unnecessary. The cost of heating is directly proportional to the annual HDD. The annual fuel cost divided by the HDD within one year, yields the heating price for HDD. The HDD is also used to compare the toughness of several winters. The HDD is also a parameter needed in the construction industry to calculate insulation, heating and cooling costs during the construction of new buildings. Considering this, when we examine Table 3, it is seen that HDD and fuel (natural gas) consumption generally parallel with each other. Since the facility needs hot water in summer months when the HDD is zero, the amount of natural gas consumed is considerably reduced. Based on these data, we can say that the plant is generally being heated correctly. It is seen that total consumption tendency is compatible with HDD in winter months when natural gas is dominant and with CDD in summer when electricity is dominant.

Table 3. Monthly energy consumption and degree day values for cooling and heating [16]

\begin{tabular}{ccccc}
\hline Months & $\begin{array}{c}\text { Electricity } \\
(\mathbf{k W h})\end{array}$ & $\begin{array}{c}\text { Natural Gas } \\
\mathbf{( m}^{\mathbf{3}} \mathbf{)}\end{array}$ & HDD & CDD \\
\hline January & 187022 & 28891 & 449 & 0 \\
February & 193215 & 20266 & 324 & 0 \\
March & 194942 & 18047 & 269 & 0 \\
April & 177819 & 16384 & 168 & 0 \\
May & 290025 & 13930 & 15 & 0 \\
June & 329737 & 9264 & 0 & 35 \\
July & 301821 & 5774 & 0 & 89 \\
August & 301670 & 6229 & 0 & 96 \\
September & 290066 & 7439 & 0 & 35 \\
October & 243369 & 4423 & 51 & 0 \\
November & 206186 & 10396 & 154 & 0 \\
December & 199155 & 16901 & 232 & 0 \\
TOTAL & $\mathbf{2 9 1 5 ~ 0 3 2}$ & $\mathbf{1 5 7 9 4 4}$ & $\mathbf{1 6 6 2}$ & $\mathbf{2 5 5}$ \\
\hline
\end{tabular}

\subsection{Air cooled refrigeration unit consumption analysis}

Figure 8 shows the efficiency pattern of the chillers. According to this graph, COP values of the most efficient devices can be seen. The efficiency of the existing chillers used for plant cooling is seen within the group that needs to be upgraded to the new generation chillers.

The quality of the devices increases from red to blue, while the COP values range from 1.2 to 7 . A unit charge of 1 unit electricity ( $\mathrm{COP}=3$ - red line) would be paid to receive 3 units of cooling with an inefficient chiller, while 0.42 units of electricity charge ( $\mathrm{COP}=7$ - blue line) would be paid for the same cooling with an efficient device. This means a cost reduction of $58 \%$.

It was seen that an energy efficiency study could be done at this point due to the operation of the cooling groups with an air-cooled system. In the air-cooled chillers, an evaporative pre-cooling circuit can be added before the cooling air inlet to improve cooling efficiency. This pre-cooling circuit increases the efficiency of the chillers and saves energy. Existing chillers do not have such a system. The operating principle of the evaporative pre-cooling system basically comes from water spray equipment installed in front of the chiller cooling air inlet panel. The 5-micron diameter pulverized water particles sprayed to this panel by means of nozzles increase the efficiency of the chiller by cooling the inlet air (according to the climate zone) by up to $10^{\circ} \mathrm{C}$.

The chillers in the plant are highly affected by the air temperature in summer. Chillers discharge the heat drawn from the inside environment to the outside environment when cooling. In the air-cooled type of the condenser (used in the plant) that provides this process, the heat load to be thrown into the environment varies according to the outdoor temperature. This is because the external air is used to cool the condenser. The performance table for the cooling group of the plant is shown in Table 4.

The variation of the same amount of cooling capacity with respect to outdoor temperatures is shown above, in Table 4. The calculation of the cooling consumption required for the efficiency calculations is shown in Figure 9.

Table 4. Refrigeration unit capacity [17]

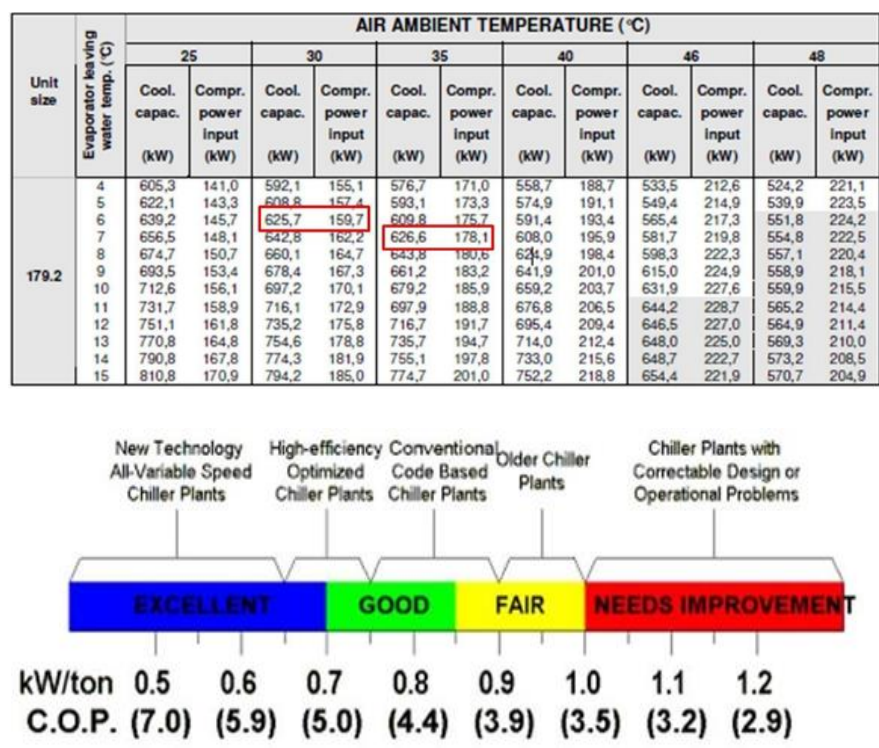

Figure 8. Chillers efficiency pattern

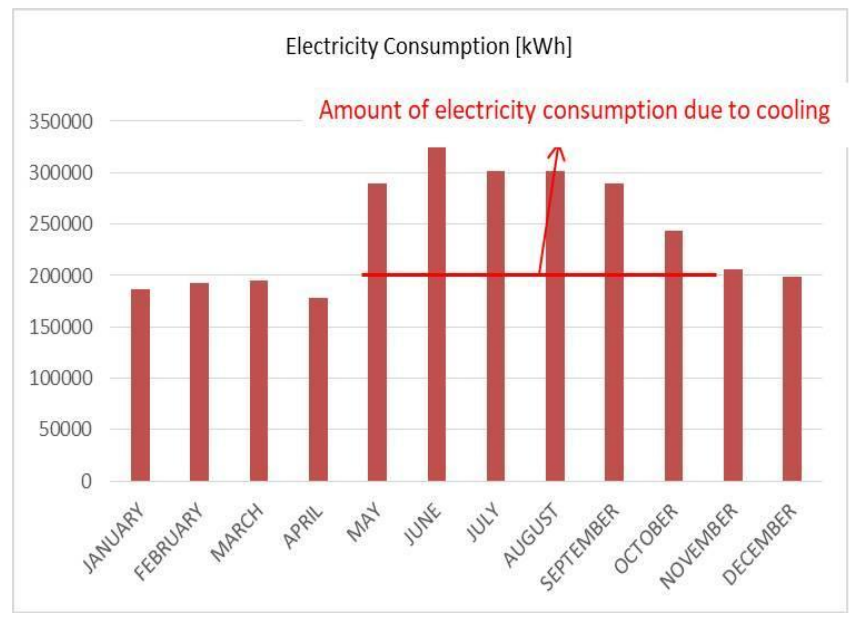

Figure 9. Electricity consumption of the plant due to cooling

As seen in Figure 9, the plant needs cooling in May, June, July, August, September, and October. The average annual electricity consumed due to the ambient cooling is around 400 $000 \mathrm{kWh}$. With the pre-cooling, it is aimed to bring the dry bulb temperature of the plant closer to the wet bulb temperature.

Dry and wet bulb temperatures for Istanbul in the summer months are around $35^{\circ} \mathrm{C}$ and $26^{\circ} \mathrm{C}$ respectively. It is predicted that the dry bulb temperature will decrease to $26^{\circ} \mathrm{C}$ as a result of pre-cooling and bringing the relative humidity to $100 \%$. Since it is difficult to catch this value, setting the system for $30^{\circ} \mathrm{C}$ was suitable. As shown in Table 4 , the efficiency would 
increase as a result of increasing the temperature with precooling before sending the outside air to the fans of the chiller. Under these conditions, the COP of the chillers reaches from 3.51 to 3.91 . In this case, efficiency will increase by $10 \%$ within the system. This means a $10 \%$ reduction in electricity consumption for cooling. As a result of the evaporative precooling, $40000 \mathrm{kWh}$ of electricity would be saved (Table 5).

The temperature values as a result of the dry bulb temperature decreasing to wet bulb temperature are shown in the psychometric diagram in Figure 10.

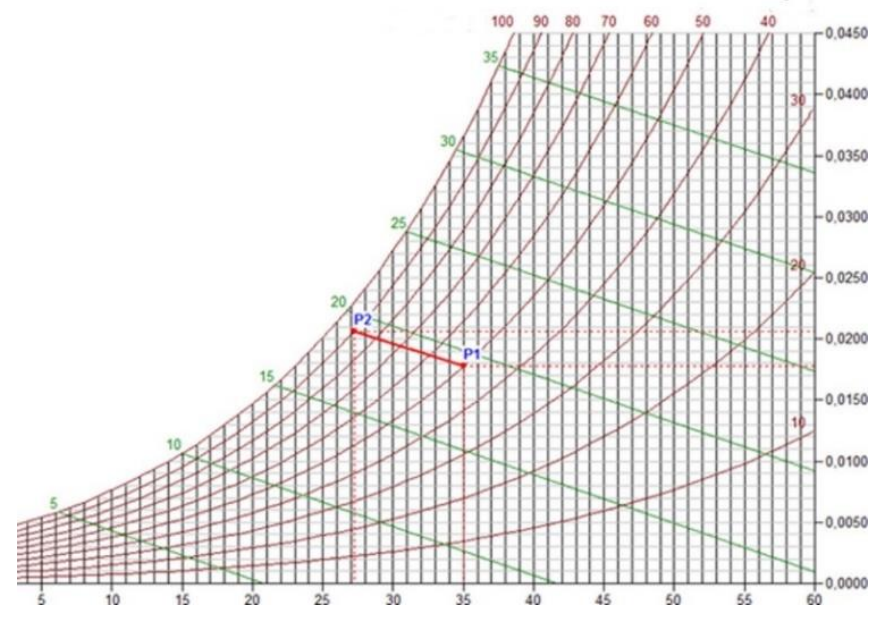

Figure 10. Schematic view of the process on psychrometric diagram

Table 5. Amount of savings and payback period

\begin{tabular}{cccccc}
\hline \multirow{2}{*}{$\begin{array}{c}\text { Energy } \\
\text { Type }\end{array}$} & \multicolumn{2}{c}{$\begin{array}{c}\text { Amount of } \\
\text { Savings }\end{array}$} & $\begin{array}{c}\text { The amount } \\
\text { of CO } \\
\text { decrease }\end{array}$ & $\begin{array}{c}\text { Invest. } \\
\text { Costs }\end{array}$ & $\begin{array}{c}\text { Payback } \\
\text { Period }\end{array}$ \\
\cline { 2 - 6 } & $\begin{array}{c}\text { Power } \\
\text { (kWh) }\end{array}$ & $\begin{array}{c}\text { Euro/ } \\
\text { Year }\end{array}$ & Tons / Year & $\begin{array}{c}\text { Euro / } \\
\text { Year }\end{array}$ & Year \\
Electricity & 40000 & 1828 & 22 & 4739 & 2.59 \\
\hline
\end{tabular}

\section{CONCLUSIONS}

Nowadays, when energy efficiency studies have gained importance in buildings, it is necessary to expand these studies especially in public buildings. In this study, ice skating rink was chosen to investigate as a sample of a public building. In the study, one-year energy consumption of the skating rink was investigated. It has been observed that the building consumes $2915032 \mathrm{kWh}$ electrical energy and $157944 \mathrm{~m}^{3}$ natural gas annually. In addition, the energy savings to be obtained with the evaporative pre-cooling system to be added to the refrigeration system were investigated. Thus, 40000 $\mathrm{kWh}$ energy savings were achieved with the evaporative precooling system.

\section{ACKNOWLEDGMENT}

This research was supported by the Istanbul Metropolitan Municipality-Enerji A.S.Turkey. The authors are gratefully thankful for their support.

\section{REFERENCES}

[1] Cao, X., Dai, X., Liu, J. (2016). Building energyconsumption status worldwide and the state-of-the-art technologies for zero-energy buildings during the past decade. Energy and Buildings, 128: 198-213. https://doi.org/10.1016/j.enbuild.2016.06.089

[2] Ma, Z., Cooper, P., Daly, D., Ledo, L. (2012). Existing Building Retrofits - Methodology and State-of-the-art. Energy and Buildings, 55: 889-902. https://doi.org/10.1016/j.enbuild.2012.08.018

[3] ASBEC. (2016). Low Carbon, High Performance: How buildings can make a major contribution to Australia's emissions and productivity goals. Australian Sustainable Built Environment Council.

[4] Tobias, L., Vavaroutsos, G. (2012). Retrofitting office buildings to $\mathrm{Be}$ green and energy-efficient optimizing building performance, tenant satisfaction, and financial return. Retrofitting buildings to be green and energyefficient. Washington.

[5] DECC. (2014). UK national energy efficiency action plan. Department of Energy and Climate Change Editor, London, United Kingdom.

[6] Alama, M., Zoua, P.X.W., Stewartb, R.A., Bertone, E., Sahin, O., Buntine, C., Marshalle C. (2019). Government championed strategies to overcome the barriers to public building energy efficiency retrofit projects. Sustainable Cities and Society, 44: 56-69. https://doi.org/10.1016/j.scs.2018.09.022

[7] BPIE. (2011). Europe's buildings under the microscope - a country-by-country review of the energy performance of buildings. Buildings Performance Institute Europe.

[8] Marquez, L., McGregor, J., Syme, M. (2012). Barriers to the adoption of energy efficiency measures for existing commercial buildings. CSIRO Energy Transformed Flagship.

[9] Bertone, E., Sahin, O., Stewart, R.A., Zou, P.X.W., Alam, M., Blair, E. (2016). State-of-the art review revealing a roadmap for public building water and energy efficiency retrofit projects. International Journal of Sustainable Built Environment, 5(2): 526-548. https://doi.org/10.1016/j.ijsbe.2016.09.004

[10] Bertone, E., Stewart, R. A., Sahin, O., Alam, M., Zou, P.X.W., Buntine, C., Marshall, C. (2018a). Guidelines, barriers and strategies for energy and water retrofits of public buildings. Journal of Cleaner Production, 174(Supplement C): 1064-1078. https://doi.org/10.1016/j.jclepro.2017.11.065

[11] Bougrain, F. (2012). Energy performance and public private partnership. Built Environment Project and Asset Management, 2(1): 41-55. https://doi.org/10.1108/20441241211235044

[12] Walker, T., Krosinsky C., Hasan L.N., Kibsey S.D. (2019). Sustainable Real Estate: Multidisciplinary Approaches to an Evolving System. A Policy Framework for Sustainable Real Estatein The European Union, Springer Nature, 77-106. https://doi.org/10.1007/978-3319-94565-1

[13] Jones, P., Lannon, S., Patterson, J. (2013). Retrofitting existing housing: how far, how much? Building Research \& Information, 41(5): 32-550. https://doi.org/10.1080/09613218.2013.807064

[14] State Council (SC). (2006). 11th Five-Year Guidelines (2006-2010). 
http://www.china.org.cn/english/features/guideline/156 529.htm.

[15] Feng, Y.P., Wu, Y., Liu, C.B. (2009). Energy-efficiency supervision systems for energy management in large public buildings: Necessary choice for China. Energy Policy, 37: 2060-2065.
[16] https://www.mgm.gov.tr/veridegerlendirme/gunderece.aspx?g=merkez\&m=34-82\&y=2017\&a=07.

[17] McQuay Product Manual Air Cooled Screw Chiller https://www.hosbv.com/data/specifications/4052\%20-\% 20Mcquay\%20MNG\%20115.2.pdf.

https://doi.org/10.1016/j.enpol.2008.12.033 